East African Medical Journal Vol. 85 No. 10 October 2008

DETERMINANTS OF UNDER NUTRITION AMONG SCHOOL AGE CHILDREN IN A NAIROBI PERIURBAN SLUM

E. J. Chesire, MSc., (Public Health), Chief Principal Lecturer, Kenya Medical Training College, Department of Community Nutrition, P.O. Box 24921-00502, Nairobi, Kenya, A. S. S. Orago, PhD, Chief Executive Officer, National AIDS Control Council, P.O. Box 61307-00200, Nairobi, Kenya, L. P. Oteba, MPH, Assistant Programme Director, Family Health OptionsKenya, P. O. Box 30581 - 00100 Nairobi, Kenya and E. Echoka MSc (Public Health), Assistant Research Officer, Kenya Medical Research Institute, Centre for Public Health Research, P.O Box 20752-00202, Nairobi, Kenya

Request for reprints to: Ms E. J. Chesire, Kenya Medical Training College, Department of Community Nutrition, P. O. Box 24921-00502, Nairobi, Kenya,

\title{
DETERMINANTS OF UNDER NUTRITION AMONG SCHOOL AGE CHILDREN IN A NAIROBI PERI-URBAN SLUM
}

\author{
E. J. CHESIRE, A.S. S. ORAGO, L.P. OTEBA and E. ECHOKA
}

\begin{abstract}
Background: Malnutrition is a major public health concern affecting a significant number of school age children influencing their health, growth and development, and school academic performance.

Objective: To establish the determinants of under nutrition among school age children between 6-12 years in a low-income urban community.

Design: A cross-sectional descriptive study.

Setting: Kawangware peri-urban slum, Nairobi, Kenya.

Subjects: Three hundred and eighty four school children aged 6 - 12 years.

Results: A total of $4.5 \%$ were wasted, $14.9 \%$ underweight and $30.2 \%$ stunted. The children who were over nine years of age were more underweight $(72.4 \%, \mathrm{p}=0.000)$ and stunted $(77.2 \%, \mathrm{p}=0.000)$ than those below eight years. The girls were more wasted $(29.1 \%$, $\mathrm{p}=0.013)$ than the boys $(18.2 \%)$, whereas the boys were more stunted $(65.7 \%, \mathrm{p}=0.003)$ than the girls $(50.7 \%)$. The other variables found to have had significant association with the nutritional status of the children were: monthly household income $(p=0.008)$, food prices $(p=0.012)$, morbidity trends $(p=0.045)$, mode of treatment $(p=0.036)$ and school attendance $(\mathrm{p}=0.044)$.

Conclusion: The findings of this study show evidently that there is under nutrition among school age children, with stunting being the most prevalent. The Ministry of Education and Ministry of Health therefore need to develop policies which can alleviate under nutrition among school age children. We also recommend that awareness be created among the school age children, parents and teachers, on the dietary requirements of both boys and girls.
\end{abstract}

\section{INTRODUCTION}

The nutritional status of children is important as it determines their health, physical growth and development, academic performance and progressin life. All children have the right to adequate nutrition, which is essential for attainment of the highest standard of health (1). Moreover, good nutrition has been reported to be the corner stone for survival, health and development in the current and succeeding generations (2).

Globally, malnutrition among school age children is becoming a major public health concern.
More than 200 million school age children are stunted and if no action is taken, and at this rate, about 1 billion stunted school children will be growing up by 2020 with impaired physical and mental development (3). In one of the largest studies in anthropometric status of school age children in low income countries like Ghana, Tanzania, Indonesia, Vietnam and India, found the overall prevalence of stunting and underweight to be high in all the five countries ranging from $48 \%$ to $56 \%$ for stunting and from $34 \%$ to $62 \%$ for underweight (4). It is therefore evident that a significant percentage of school age children suffer from malnutrition, affecting their 
health and nutritional status, and school academic performance.

The consequences of Protein Energy Malnutrition (PEM) among school age children are retarded physical and mental development, which are associated with non-enrolment or late enrolment to school (2). Malnutrition impairs the immune system, making children more vulnerable to infections and less interested in the environment they live in, than are well nourished peers. The combination of malnutrition, infections and poor environmental sanitation affects their health and nutritional status thus reducing a child's learning opportunities (5). It is important to note that well nourished children brought up in a healthy nurturing environment, grow stronger, taller and become adults that are more productive, maintaining high levels of functionality and produce healthy offspring in the future (1).

The school age children form a substantial fraction of the world's population, estimated at $24 \%$ of the population of developing countries and about $15 \%$ in industrialised countries (6). In Kenya, school children aged 5-14 years form the largest fraction $(27.5 \%)$ of the total population, making their nutritional status to be of importance (7). In addition, a concern was raised regarding the health and nutritional status of school age children which stated that not much emphasis has been put on this group, instead the focus of most countries has been on child survival and welfare programmes which target the pre-school children only (6). Therefore the health and nutritional status of school age children is of paramount importance to all nations of the world, as this group forms the future generation. This hence calls for necessary attention to be given to this group of children, as it will have an impact on the socio and economic development of a country.

This study therefore attempted to determine the factors that influence the nutritional status of school age children being an area where not much research has been done. In concurrence, it is reported that data on the growth of school age children across countries are difficult to find (8). This study sought to add knowledge on existing body of literature, knowing that under nutrition has long term effects on the children's health and nutritional status. The results of this study hence can form a basis for planning strategic intervention programmes which will improve the health and nutritional status, and academic performance of these children.

\section{MATERIALS AND METHODS}

A cross-sectional descriptive study was carried out in Kawangware peri-urban slum, Nairobi, Kenya, from
July 2006 to November 2006. The objective was to establish the determinants of under nutrition among school age children aged $6-12$ years. The sample size of the target children were 384 . One child per household was included in the study.

Cluster sampling was used in identifying the villages. Five clusters out of the thirteen were selected randomly with the assumption that they represent all the clusters because they had similar characteristics.

A structured interview schedule was administered to parents and caregivers to obtain sociodemographic information and socio-economic status of the household heads, food availability information, socio-demographic information of the index child and a 24-hour dietary recall method to get the dietary habits of the target children.

Anthropometric measurements were taken to assess the nutritional status of the school age children with cut off points at -2SD as recommended by World Health Organisation (WHO) (9). An observation checklist and a key informant interview guide were used to get more information on target population and socio-economic status of the household.

Data were analysed using descriptive statistics; Pearson's Chi-square test and Fisher Exact test were used to determine associations. The level of significance was fixed at $0.05(p=0.05)$. The diets consumed by the index children in the last 24 hours were analysed using the Nutrisurvey package. Child anthropometry data were analysed using Anthro' software package.

\section{RESULTS}

A total of 384 school children aged between 6 to 12 years were included in the study. The nutritional status of the children was determined using the three nutritional indicators namely; weight for height, weight for age and height for age, using the National Centre for Health Statistics reference using Z-scores with cut off points of-2SD (9). All these indicators were used in establishing significant associations between the children's nutritional status (dependent variable) and the various independent variables.

Demographic data of the index child: The children aged between 6-12 years formed the target population. Children aged six years were $32.3 \%$ and those aged 9-12 were $32 \%$ (Figure 1). Both sexes were fairly represented in the study with $181(47.1 \%)$ being males and $203(52.9 \%)$ were females, a ratio of almost 1: 1. Most (92.2\%) of these children were either the sons or daughters of the household heads. 
Figure 1

Distribution of study children by age (years)

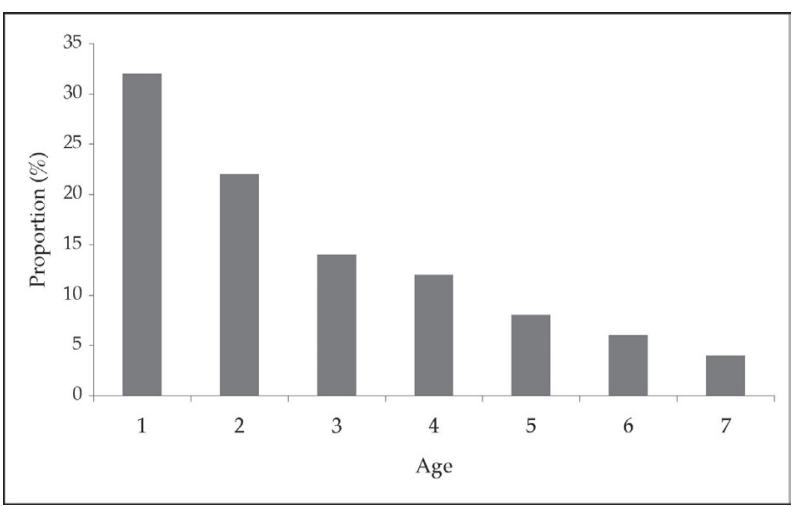

Nutritional status of the study population: From the findings of this study, using Z-scores with cut off points of -2SD, the overall nutritional status of the target children showed that only $4.5 \%$ were wasted (low weights for height), 14.9\% were underweight (low weights for age) and 30.2\% were stunted (low heights for age) (Table 1). The nutritional status of the children according to sex using Z-scores, showed $4.5 \%$ males and $4.4 \%$ females were wasted (Table 2). In weight for age, $17.7 \%$ males and $12.3 \%$ females were underweight (Table 3). In height for age, $37.1 \%$ males and $24.2 \%$ females were stunted (Table 4).

Age of the index children: The ages of the children and their current nutritional status were found to be highly significant $\left(X^{2}=24.254, P=0.000\right)$, with $72.4 \%$ children aged between $9-12$ years underweight compared to children below eight years. A strong significant association $\left(X^{2}=27.999, P=0.000\right)$ was found in height for age also for children above nine years old, being more (77.2\%) stunted than the other age groups (Table 5).

Table 1

The overall nutritional status of all target children

\begin{tabular}{llcc}
\hline Indicator & Nutritional Status & Frequency & Proportion (\%) \\
\hline Weight for height & Well- nourished $(\geq 2 \mathrm{SD})$ & 367 & 95.5 \\
& Malnourished $(\leq 2 \mathrm{SD})$ & 17 & 4.5 \\
Weight for age & Well- nourished $(\geq 2 \mathrm{2SD})$ & 327 & 85.1 \\
& Malnourished $(\leq 2 \mathrm{SD})$ & 57 & 14.9 \\
Height for age & Well- nourished $(\geq 2 \mathrm{SD})$ & 268 & 69.8 \\
& Malnourished $(\leq 2 \mathrm{SD})$ & 116 & 30.2 \\
\hline
\end{tabular}

$\mathrm{SD}=$ Standard Deviation

Table 2

Nutritional status (weight for height) of the children by sex

\begin{tabular}{llcc}
\hline Sex of the index child & Nutritional status & Frequency & Proportion (\%) \\
\hline \multirow{2}{*}{ Males } & Normal & 148 & 81.8 \\
& Mild wasting & 25 & 13.7 \\
& Moderate wasting & 7 & 3.9 \\
& Severe wasting & 1 & 0.6 \\
Females & Normal & 144 & 70.9 \\
& Mild wasting & 50 & 24.6 \\
& Moderate wasting & 9 & 4.4 \\
\hline
\end{tabular}


Table 3

Nutritional status (weight for age) of the children by sex

\begin{tabular}{llcc}
\hline Sex of the index child & Nutritional status & Frequency & Proportion (\%) \\
\hline \multirow{2}{*}{ Males } & Normal & 75 & 41.4 \\
& Mild underweight & 74 & 40.9 \\
& Moderate underweight & 31 & 17.1 \\
& Severe underweight & 1 & 0.6 \\
Females & Normal & 101 & 49.8 \\
& Mild underweight & 77 & 37.9 \\
& Moderate underweight & 23 & 11.3 \\
& Severe underweight & 2 & L0 \\
\hline
\end{tabular}

Table 4

Nutritional status (height for age) of the children by sex

\begin{tabular}{llcc}
\hline \multirow{2}{*}{ Sex of the index child } & Nutritional status & Frequency & Proportion (\%) \\
\hline \multirow{2}{*}{ Males } & Normal & 62 & 34.3 \\
& Mild stunting & 52 & 28.6 \\
& Moderate stunting & 41 & 22.7 \\
& Severe stunting & 26 & 14.4 \\
Females & Normal & 100 & 49.3 \\
& Mild stunting & 54 & 26.5 \\
& Moderate stunting & 20 & 9.9 \\
& Severe stunting & 29 & 14.3 \\
\hline
\end{tabular}

Table 5

Association between child nutritional status and age

\begin{tabular}{|c|c|c|c|c|c|c|c|}
\hline \multirow[t]{2}{*}{ Variable } & \multirow{2}{*}{$\begin{array}{l}\text { Nutrition } \\
\text { indicator }\end{array}$} & \multirow{2}{*}{$\begin{array}{l}\text { Category } \\
\text { (years) }\end{array}$} & \multirow{2}{*}{$\begin{array}{l}\text { Nutritional } \\
\text { status }\end{array}$} & \multirow[t]{2}{*}{ No. } & \multirow[t]{2}{*}{$(\%)$} & \multicolumn{2}{|c|}{ Significance level } \\
\hline & & & & & & $X^{2}$ & P-value \\
\hline \multirow[t]{12}{*}{ Age } & \multirow{6}{*}{$\begin{array}{l}\text { Weight for } \\
\text { height }\end{array}$} & \multirow[t]{2}{*}{6} & Normal & 93 & 75.0 & & \\
\hline & & & Wasted & 31 & 25.0 & & \\
\hline & & \multirow[t]{2}{*}{ 7- 8} & Normal & 102 & 74.5 & & \\
\hline & & & Wasted & 35 & 25.5 & 0.801 & $0.670^{*}$ \\
\hline & & \multirow[t]{2}{*}{$9-12$} & Normal & 97 & 78.9 & & \\
\hline & & & Wasted & 26 & 21.1 & & \\
\hline & \multirow{6}{*}{$\begin{array}{l}\text { Weight for } \\
\text { age }\end{array}$} & \multirow[t]{2}{*}{6} & Normal & 66 & 53.2 & & \\
\hline & & & Underweight & 58 & 46.8 & & \\
\hline & & \multirow[t]{2}{*}{$7-8$} & Normal & 76 & 55.5 & & \\
\hline & & & Underweight & 61 & 44.5 & 24.254 & $0.000^{* *}$ \\
\hline & & \multirow[t]{2}{*}{$9-12$} & Normal & 34 & 27.6 & & \\
\hline & & & Underweight & 89 & 72.4 & & \\
\hline
\end{tabular}




$\begin{array}{lllllll}\text { Height for } & 6 & \text { Normal } & 64 & 51.6 & & \\ \text { age } & & \text { Stunted } & 60 & 48.4 & & \\ & 7-8 & \text { Normal } & 70 & 51.1 & & \\ & & \text { Stunted } & 67 & 48.9 & 27.999 & 0.000^{* *} \\ & 9-12 & \text { Normal } & 28 & 22.8 & & \\ & & \text { Stunted } & 95 & 77.2\end{array}$

* The P-value was $>0.05$ indicating that there was no significant association between age of the index children and their weight for height.

** The P-values were $<0.05$ indicating that there was strong significant association between the age of the index children and their weight for age and height for age.

Table 6

Relationship between child nutritional status and sex

\begin{tabular}{|c|c|c|c|c|c|c|c|}
\hline \multirow[t]{2}{*}{ Variable } & \multirow{2}{*}{$\begin{array}{l}\text { Nutrition } \\
\text { indicator }\end{array}$} & \multirow[t]{2}{*}{ Category } & \multirow{2}{*}{$\begin{array}{l}\text { Nutritional } \\
\text { status }\end{array}$} & \multirow[t]{2}{*}{ No. } & \multirow[t]{2}{*}{$(\%)$} & \multicolumn{2}{|c|}{ Significance level } \\
\hline & & & & & & $X^{2}$ & P-value \\
\hline \multirow[t]{12}{*}{ Sex } & \multirow{4}{*}{$\begin{array}{l}\text { Weight for } \\
\text { height }\end{array}$} & \multirow[t]{2}{*}{ Male } & Normal & 148 & 81.8 & & \\
\hline & & & Wasted & 33 & 18.2 & \multirow{3}{*}{6.162} & \multirow{3}{*}{$0.013^{* *}$} \\
\hline & & \multirow[t]{2}{*}{ Female } & Normal & 144 & 70.9 & & \\
\hline & & & Wasted & 59 & 29.1 & & \\
\hline & \multirow{4}{*}{$\begin{array}{l}\text { Weight for } \\
\text { age }\end{array}$} & \multirow[t]{2}{*}{ Male } & Normal & 75 & 41.4 & \multirow{4}{*}{2.666} & \multirow{4}{*}{$0.103^{*}$} \\
\hline & & & Underweight & 106 & 58.6 & & \\
\hline & & \multirow[t]{2}{*}{ Female } & Normal & 101 & 49.8 & & \\
\hline & & & Underweight & 102 & 50.2 & & \\
\hline & \multirow{4}{*}{$\begin{array}{l}\text { Height for } \\
\text { age }\end{array}$} & \multirow[t]{2}{*}{ Male } & Normal & 62 & 34.3 & \multirow{4}{*}{8.835} & \multirow{4}{*}{$0.003^{* *}$} \\
\hline & & & Stunted & 119 & 65.7 & & \\
\hline & & \multirow[t]{2}{*}{ Female } & Normal & 100 & 49.3 & & \\
\hline & & & Stunted & 103 & 50.7 & & \\
\hline
\end{tabular}

* The P-value was $>0.05$ indicating that there was no significant association between sex of the index children and their weight for age.

** The P-values were $<0.05$ indicating that there was strong significant association between the sex of the index children and their weight for height and height for age.

Table 7

Relationship between child nutritional status and household income

\begin{tabular}{|c|c|c|c|c|c|c|c|}
\hline \multirow{2}{*}{ Variable } & \multirow{2}{*}{$\begin{array}{l}\text { Nutrition } \\
\text { indicator }\end{array}$} & \multirow[t]{2}{*}{ Category } & \multirow{2}{*}{$\begin{array}{l}\text { Nutritional } \\
\text { status }\end{array}$} & \multirow[t]{2}{*}{ No. } & \multirow[t]{2}{*}{$(\%)$} & \multicolumn{2}{|c|}{ Significance level } \\
\hline & & & & & & $X^{2}$ & P-value \\
\hline \multirow{8}{*}{$\begin{array}{l}\text { Average } \\
\text { house } \\
\text { hold }\end{array}$} & \multirow{6}{*}{$\begin{array}{l}\text { Weight for } \\
\text { height } \\
\text { income }\end{array}$} & \multirow[t]{2}{*}{$<3000$} & Normal & 79 & 81.4 & \multirow{8}{*}{3.666} & \multirow{8}{*}{$0.138^{*}$} \\
\hline & & & Wasted & 18 & 18.6 & & \\
\hline & & $3001-5000$ & Normal & 87 & 74.4 & & \\
\hline & & & Wasted & 30 & 25.6 & & \\
\hline & & $>5000$ & Normal & 62 & 68.9 & & \\
\hline & & & Wasted & 28 & 31.1 & & \\
\hline & \multirow{2}{*}{$\begin{array}{l}\text { Weight for } \\
\text { age }\end{array}$} & \multirow[t]{2}{*}{$<3000$} & Normal & 43 & 44.3 & & \\
\hline & & & Underweight & 54 & 55.7 & & \\
\hline
\end{tabular}




\begin{tabular}{lllllll} 
& \multirow{2}{*}{$3001-5000$} & Normal & 60 & 51.3 & & \\
& & & & & \\
& & Underweight & 57 & 48.7 & 6.679 & $0.035^{* *}$ \\
Height for & & Normal & 30 & 33.3 & & \\
age & & Underweight & 60 & 66.7 & & \\
& & Normal & 33 & 34.0 & & \\
& \multirow{2}{*}{$30001-5000$} & Stunted & 64 & 66.0 & & \\
& & Normal & 59 & 50.4 & & \\
& & Stunted & 58 & 49.6 & 7.361 & $0.025^{* *}$ \\
& & Normal & 32 & 35.6 & & \\
& & Stunted & 58 & 64.4 & & \\
\hline
\end{tabular}

* The P-value was $>0.05$ indicating that there was no significant association between the average household income and the weight for height of the index child.

** All the P-values were $<0.05$ indicating that there was significant association between the average household income and weight for height and height for age of the index child. Ksh. $67.5=1$ US \$

Sex of the index child: The sex of the children and their nutritional status (height for age) were significantly associated $(\mathrm{p}=0.013)$, with the girl child being more wasted $(29.1 \%)$ than the boy child (18.2\%). However, the proportion of stunted children was higher $(65.7 \%)$ among the male children than the females $(50.7 \%)$ $(\mathrm{p}=0.003)$ (Table 6).

Morbidity trends: The children who were reported to have been sick in the last two-weeks prior to the interview date were $43 \%$, with $44.8 \%$ treated at the health facility. There was significant association $\left(X^{2}=\right.$ 4.023, $\mathrm{p}=0.045$ ) between child nutritional status and children who have been sick, which affected the height for age, in that they were more $(63.6 \%)$ stunted children as compared to those who were not sick.

Mode of treatment given during sickness: Children who were treated at home had a higher percentage $(34.8 \%$, $X^{2}=6.652, p=0.036$ ) of wasting (weight for height) than those treated at the health centre $(16.2 \%)$.

School attendance: The proportion of those who were stunted was found to have significant association $\left(X^{2}=4.039, p=0.044\right)$ with school attendance. Those children who did not attend school were more (69.4\%) stunted than those who attended school (55.6\%).

24-hour dietary recall: Most (93\%) of the children had three or more meals in the last 24 hours with $43 \%$ having had balanced meals. However, this did not have any significant influence on the nutritional status of the target children.

Demographic characteristics of the households: A higher proportion $(54.7 \%)$ of the household head was in the age range of $30-39$ years, with a mean of 36 years, median is 35 years. More than two thirds
(71.9\%) of the household heads interviewed were married. The literacy level was high with $94.6 \%$ of all household heads being literate. On employment, $35.7 \%$ were on monthly employment, while $32.3 \%$ were casuals, $25.3 \%$ were self -employed and $7.8 \%$ were either unemployed or were housewives. Over two-thirds $(72.1 \%)$ of the households lived in semipermanent houses, with $18.2 \%$ living in temporary houses and only $9.6 \%$ lived in permanent houses. Nearly a half (49.7\%) of the households had five to seven family members and those with two to four members were $43.2 \%$, and only $7 \%$ had more than eight family members. All these factors did not have any significant association with the nutritional status of the target population.

Average household income: The monthly income of the households ranged from less than Ksh. 3000 (US\$ 45) to over Ksh. 5000 (US\$ 74), with a third (31.9\%) earning less than Ksh. 3000 (US\$ 45), 38.5\% earning between Ksh. 3001 - 5000 (US\$ 45 -74), and those earning Ksh. 5000 (US\$ 74) and above were only $29.6 \%$. There were more underweight children $(66.7 \%)$, among households whose monthly income was more than Ksh. 5000 (US\$ 74) per month $\left(X^{2}=\right.$ $6.679, \mathrm{p}=0.035)$ than those whose monthly income ranged between Ksh. 3000-5000 (US\$ 45 - 74) having $48.7 \%$ of their children being underweight. However, the proportion of stunted children $(68.7 \%)$ was significantly $\left(X^{2}=7.361, \mathrm{p}=0.025\right)$ higher among households whose average income was less Ksh. 3000 (US\$ 45) (Table 7).

Money spent on food: From their earnings, the average spending on food purchases were as follows: $24.2 \%$ (0.24) spent between Ksh. 100 - 1000 (US\$1-15), 47.4\% (0.47) Ksh. 1001 - 3000 (US\$ 15 - 45), and 26\% (0.26) spentover Ksh.3001 (US\$45) per month. Thisimplied 
that a high proportion (0.47) of the households spent between Ksh. 1001 - 3000 (US\$ 15-45) monthly on food. However, this did not influence the nutritional status of the children.

Food prices: Among the households, $48.2 \%$ found food to be expensive, while $50.5 \%$ said it was affordable and only $1.3 \%$ reported that food was cheap. The results showed that food prices affected the nutritional status of the children $\left(X^{2}=6.383, p=0.012\right)$ in weight for height. Those who reported that food is expensive had $30.4 \%$ wasted children compared to $19.3 \%$ of those who reported that food is affordable.

Adequacy of energy and protein giving foods: The households that reported to have had adequate energy foods were $58.6 \%$, with only $28.3 \%$ having had adequate protein and $81 \%$ had adequate green vegetables. Regarding energy and protein content in the diet taken in the last 24 hours by the study children, only $12.3 \%$ had adequate energy giving foods, with $78.4 \%$ having had adequate protein. This did not have any impact on the nutritional status of the target children.

In summary therefore, the variables which were found in this study to have an association or influenced the dependent variable (nutritional status of the target children) were age and sex of the target children, morbidity and mode of treatment, school attendance and household income and the prices of food.

\section{DISCUSSION}

The objective of this study was to establish the determinants of under nutrition among school age children in a peri-urban slum in Nairobi. The overall nutritional status of the study children found that $4.5 \%$ were wasted, $14.9 \%$ were underweight and $30.2 \%$ were stunted. Asimilar study was carried out in Kibera in 1991 amongst school age children between 6-10 years, $24.2 \%$ of the children were underweight, $15.8 \%$ were stunted and only one child was wasted (10). When these results were compared together, it is distinctive that children from both areas vary in their nutritional status, despite living in similar environments.

Another study donein Tanzania, Rukwa and Mbeya regions among school age children between 7-13 years showed the prevalence offender nutrition, where $19 \%$, were underweight, $39 \%$ stunted and only $2 \%$ were wasted. Except for wasting which was lower than that for children from Kawangware, the proportion of the underweight and stunted children was higher. Stunting amongst children in the study area was the most prevalent nutritional problem. Studies in other countries also raveled higher rates of stunting, for example, Ethiopia $64 \%$, Bhutan
56\%, Bangladesh 55\%, India 52\%, and Pakistan 50\% (11). Numerous studies from developing countries established that physical stunting is closely linked to impaired mental development, even after allowing for the relationship of both stunting and poor mental development with socio-economic deprivation. It is therefore envisaged that if this current trend continues in most countries, then about 1 billion stunted children worldwide will be growing up by 2020 with impaired physical and mental development (3).

In agreement with other studies done in various countries, the ages of the children strongly influenced their nutritional status. As the children advance in years, they get malnourished as opposed to when they are eight years and below. This study showed that children aged more than nine years were more underweight and stunted than those aged less than eight years. These findings compared well with what was found in Ghana, Tanzania, Indonesia, Vietnam and India whereby in all the five countries, there was a trend for Z-scores for weight for age and height for age to decrease with age, as children got older they became progressively shorter and lighter relative to the reference population (12). In justifying this further, a sample survey done in 1997 in 13 districts in Kenya revealed that children beyond six years needed special attention. The data collected showed that as they grew older, the family's capacity to provide for and care for them wanes; instead, they rely on these children to contribute to the family's welfare (13).

Sex of the target children was also a significant predictor of their nutritional status. The female children were more wasted than the male children, but a higher proportion of the male children were stunted than females. However, these findings differ with observations from Ghana, Tanzania, Indonesia, Vietnam and India which observed that the boys in these countries tended to be both stunted and underweight than girls (12).

Morbidity trend also influenced the nutritional status (height for age) of the children. The affected children were those who were sick two weeks prior to the interview date having suffered from respiratory tract infection, malaria, diarrhoea and vomiting, and pneumonia. In Bangladesh, a prospective cohort study of school age children showed that infections and, especially diarrhoea was found to retard weight gain and slow linear growth (12).

In addition, the kind of treatment received by the children influenced their nutritional status (weight for height). The children who were treated at home or given no treatment were more wasted than those treated at the health facility. Of importance also was the school attendance, whereby those children who did not attend school were more stunted, than those who were attending school. This is an indication 
that school attendance has positive influence on the nutritional status of the children; hence school attendance should be encouraged for more children to be reached through school health and nutrition programme. This is because schools are vitally important settings through which to promote good nutrition and provide nutrition interventions, as they offer more effective, efficient and equal opportunities than any other setting to promote health and healthy eating (14).

From the findings of this study, the 24-hour dietary recall did not have significant influence on the nutritional status of the children. Despite this, more than half of the target children were underweight and stunted. This could be associated with the composition, quality and quantity of the meals the children consumed, whichimpacts on their nutritional status. For their optimal growth and development, the school age children require adequate nutritious food to meet their daily nutritional requirements (5).

The majority of these study children were drawn from families whose heads of the household ages ranged between 30 - 39 years. A high proportion $(94.6 \%)$ of the respondents were literate which compared well with the findings of Kenya Demographic and Health Survey 2003 report (15), which reported $92.2 \%$ literacy level in Nairobi. Despite this, it did not have any influence on the nutritional status of these children, although many studies have proved that education of parents' have positiveimpact on the health and nutritional status of their children (14).

Another significant predictor of nutritional status of the target children was the level of household income. The families whose income was higher $>$ Ksh. 5000, (US\$ 74), their children were more likely to be underweight whereas children from families which had less income $<$ Ksh. 3000 (US\$ 45), were more likely to be stunted. Contrary, to this, another study found higher incomes improves the nutritional status of children (16). From this study, the people with lower incomes were mostly casuals, and received their wages daily or on weekly basis and their priority was purchase of food. Despite this effort, the quantity and quality of the diets is compromised. Whereas, those households whose income was higher were being paid at the end of the month, hence buy food in bulk at the beginning of the month, which may not sustain them through out the month. The family eats well just after one payday than before the next pay. There seems little doubt that a change to weekly payment of wages would improve the diet of wage earners and their families (17). The availability of food in households depends mostly on their prices. This study found food prices to have an impact on the nutritional status of the school age children, affecting their heights for height.

In regards to adequacy of energy and protein foods consumed by the target children, this study found that most of them had adequate proteins and less of the energy giving foods. Despite this, the inadequate consumption of energy giving foods was not found to be a predictor of the nutritional status of the target children. Irrespective of being insignificant, the adequate intake of energy giving foods for these children is necessary for their growth, development, and contributes to better academic performance, as well as providing them with energy to enable them participate in extra curricula activities.

In conclusion, the findings of this study showed that under nutrition is prevalent in the study area, with stunting affecting a higher percentage of the children. The factors that significantly influenced the nutritional status of the study population were; age and sex of the target children, monthly household income, and food prices, morbidity trends, mode of treatment and school attendance.

It is therefore recommended that the Ministry of Education and Ministry of Health ought to conduct health and nutrition education programmes aimed at improving the health and nutritional status of these children. We also recommend that awareness be created among the school age children, parents and teachers, on the dietary requirements of both boys and girls. In addition, comprehensive school feeding programmes are implemented to alleviate under nutrition among school age children from the peri-urban slums.

\section{REFERENCES}

I. WHO.Child and AdolescentHealth andDevelopment Progress Report 2002- 2003. France, WHO Library Cataloguing-in-Publication Data, 2004; 10-17.

2. WHO. The World Health Report: Make Every Mother and Child Count, France, WHO Library Cataloguingin-Publication Data, 2005; 1-9.

3. UNU. Food and Nutrition Bulletin, (Supplement) UNICEF, Volume 21, Number 3, 2000; 6-17.

4. Drake, L., Maier, C. Jukes, M. and Patrikios, A. SchoolAge Children: Their Health and Nutrition prepared for Partners in Child Development, 2002.

5. Evans, J. L., Myers, R. G. and Ilfeld, E. M. Early Childhood Counts: A Programming Guide for Early Childhood Care for Development, Washington D.C., The World Bank, 2000.

6. Leslie, J. and Jamison, T. D. Health and Nutrition considerations in Education Planning I. Educational Consequences of Health Problems among School Age Children, Paper presented at ACC / SCNSymposium on Nutrition and Schooling and UNESCO/ 
Rockefeller Foundation Workshop, Paris, UNESCO HQs, 1990.

7. GOK. Household Health and Expenditure and Utilisation Survey Report, A publication of the Government of Kenya by Ministry of Health $(\mathrm{MOH})$ 2003; 15-17.

8. Anwer, I. and Awan, J. A. Nutritional status comparison of rural with urban school children in Faisalabad District, Pakistan. Rural and Remote Health 3 (online), 2003: 130. Available from: http://www.rrh. org.au

9. WHO. Measuring Change in Nutrition Status. WHO, Geneva, 1983.

10. Mugo, R. W. Nutritional Status and its determinants amongst School Age Children (6 - 10 years) in a Low Income Urban Community of Nairobi. MPH Thesis, University of Nairobi, 1991.

11. SCN News. Nutrition Relevant Action in Tanzania. UNICEF, 1993; 236.

12. SCN News. School Age Children: Their Health and Nutrition. SCN News; Number 25, 2002; 4-14.
13. GOK/UNICEF. 1999-2003 Country Programme of Cooperation between Government of Kenya and United Nations Children's Fund: Master Plan of Operations, Kenya, Nairobi, 1999; 11: 4-5.

14. FAO and WHO. Healthy Nutrition: An Essential Element of a Health-Promoting School, WHO Information Series on School Health - Document 4. University Press, New York, 1998; 8-10.

15. GOK. Kenya Demographic and Health Survey 2003, Central Bureau of Statistics, Nairobi, 2004; 16 -17.

16. Wasike, R. L. Maternal and Child Care Practices related to the Nutritional Status of Under-five year old Children in Banpong Hospital. MPHC Thesis, Mahindol University, Thailand, 2000.

17. Stephens, C. Achieving Urban Food and Nutrition Security in the Developing World: A 2020 Vision for Food, Agriculture, and the Environment - Focus 3 - August 2000, IFPR1, 2000. 